\title{
Booms in Agricultural \& Non-Agricultural Prices: Who Is Responsible?
}

\author{
Peter Cincinelli \\ University of Bergamo
}

\author{
Austin J. Damiani \\ Minneapolis Grain Exchange
}

\author{
Ameeta Jaiswal-Dale \\ University of St. Thomas
}

Giovanna Zanotti

University of Bergamo

\begin{abstract}
This paper investigates the cross-market price linkages in actively traded, major agricultural and energy commodities, impacted by three global episodes over the 1971-2018 time frame. As episodes, we identify the rapid increase of prices during the 1970's, the commodity depression of the 1990's, the credit crunch and sovereign debt crisis in the 2000's. We find that during the rapid price increase in 1970's, all the major agricultural commodity are influenced by a series of events, including the Soviet Union's unexpected purchase of a large amount of grain in the global markets. During the commodity depression, a negative relationship is shown by all the agricultural commodities. The credit crunch and sovereign debt shows a positive impact for only wheat whereas oats show a negative relationship. We also investigate these three episodes on non-agricultural commodity sectors (wood and animal, precious metal and energy sector). The paper demonstrates the increase in the energy prices supporting the cross-market linkages between the stock and crude oil markets as a result of the financialization of commodities.
\end{abstract}

Keywords: agricultural commodity markets, commodity price fluctuations, financialization of commodities, futures contracts, price discovery

\section{INTRODUCTION}

Over the last several years, the rise in food commodity prices has been part of a general increase in global commodity prices, including minerals, metals and energy. Although the food commodity index rose to a historic high over the past years, the indices for all commodities, particularly for crude oil, have significantly out paced it. According to the International Monetary Fund (IMF) (2018), world market prices for food commodities rose more than $75 \%$ from the end of 2006 to July 2008. In particular, between January 
2002 and July 2008, the IMF index for food commodities rose $130 \%$, compared with $330 \%$ for all commodities and $590 \%$ for crude oil.

The wide fluctuations of agricultural commodity prices from 2008 to 2010 have attracted the interest of academics and policy makers and triggered an intensive debate on the causes of these price booms. There seems to be a consensus among researchers that this path cannot be related to a single factor. Several factors contributed to the price increase, such as simultaneously occurring crop failures in major production regions of the world (Headey \& Fan, 2008; Sarris, 2009) and an increase in the demand for biofuels (Roberts \& Schlenker, 2009).

The Economic Research Service (ERS) of the United States Department of Agriculture (USDA) (2008) has identified a set of interrelated factors that include long-term supply and demand trends. Although no single factor is responsible for the rapid escalation of food prices but as also more recent phenomena such as higher energy prices, increased biofuel production, depreciation of the U.S. dollar, adverse weather and policy responses to domestic food price inflation. Among these, the grain sector of commodities has risen more sharply to historic highs.

However, the most interesting debate among the several causes is about the impact of financial investors and speculative activities on the prices of agricultural commodity futures. Some researchers, indeed, argue that the large inflow of financial capital has impacted the price dynamics of commodity futures - i.e., financialization of commodity markets (Tang \& Xiong, 2012; Büyükşahin \& Robe, 2014; Ordu et al., 2018; Hu et al., 2020).

This paper aims to shed further light on these debates while investigating the price movements, impacted by global episodes during 1971:1 and 2018:12 time frame, in actively traded agricultural commodities. The investigation also covers the spill over effect into related non- agricultural sectors of wood and energy. The data set thus is composed of the major actively traded agricultural commodities such as oats, wheat, corn and soybeans. As episodes, we identify: [i] the rapid price increases during the 1970's; [ii] the commodity depression of the 1990's; [iii] the credit crunch and sovereign debt crisis in the 2000's. For each of them, we will explain the reasons for price surges. The empirical results show that during the rapid increase in 1970 s, all the major agricultural commodity prices are positively influenced by a series of events, including the Soviet Union's unexpected purchase of a large amount of grain in the global markets. During the commodity depression time period, a negative relationship is common to all the agricultural commodities. The credit crunch $\&$ sovereign debt shows a positive and statistically significant impact for only the wheat commodity whereas the oats show a negative relationship.

In particular, during the 1970s, we find that the entry of the Soviet Union (and other centrally planned economies) into the global markets represented a significant change in agricultural commodity sector and started a period of strong growth in agricultural commodity trade that lasted throughout the 1970s. This is consistent with found by Peters et al. (2009), who demonstrate this feature on the value of global agricultural commodity imports grew $4.8 \%$ a year, while the value of U.S. agricultural exports grew at an annual rate of $11.7 \%$.

The study also investigates the main effects of these episodes for non-agricultural commodity sector such as wood \& animal, precious metal and energy sector. We find that energy prices play a key role in the determination of food prices supporting the cross-market linkages between the stock and crude oil markets after the financialization of commodities (Tang \& Xiong, 2012; Bampinas \& Panagiotidis, 2017).

Our choice of these three periods relies on the fact that from 2006 to 2008 the world attention was devoted to the rapid increase in agricultural commodity prices. However, this was not unique. Since the beginning of the 20th century, there have been several periods of dramatic agricultural price increases such as the rapid increase during the 1970's and the commodity depression of the 1990's, which raised concerns that permanent changes in the agricultural market environment were occurring. The choice of the European agricultural markets relies on the scarcity of studies. In particular, the credit crunch and the sovereign debt crisis in the 2000's aims to capture the institutional changes in the European agricultural markets such as the abolition of high guaranteed fixed prices, which has led to international competition and higher hedging needs for European producers. 
Our study helps to understand the importance of the drivers of commodity price booms and busts for the global economy in different ways. Standard economic theory suggests that changes in price level will be governed by the laws of supply and demand, but it is unclear whether such extreme price swings over protracted periods can be justified, leading to suggestions that they may arise from speculation.

According to Bernanke (2006), a significant portion of income and welfare is associated with these commodity prices. In addition, they influence the distribution of income in some nations due to their ownership of these natural resources.

The role of speculation has also been discussed from an economic perspective. Sanders et al. (2010) and Sanders \& Irwin (2010) argue that speculation contributes to price discovery in information efficient markets, provides liquidity to illiquid markets and is a necessary counterpart to hedging activities. On the other hand, both rational and irrational speculation can set price trends which may be self-enforced by herd behavior and result in prices bubbles.

Moreover, we argue that the assessment of the long-run drivers of commodity prices could help the study of the policy implications related to resource rich countries with solid and economic infrastructure, trade openness, and high investments in alternative technology (Van der Ploeg, 2011).

For our investigation the paper extends the traditional correlation analysis (Baig \& Goldfajn, 1999; Calvo, 1999; King \& Wadhwani, 1990; Bampinas \& Panagiotidis, 2017) by offering further evidence on different commodities and under different market circumstances.

The remainder of this paper is organized as follows: Section 2 presents the literature review on commodities prices while Section 3 provides some salient facts of the major commodities investigated in this paper. Section 4 provides data and covers the empirical process. Section 5 discusses the empirical results. Section 6 concludes and provides further questions for investigation.

\section{LITERATURE REVIEW}

From the low commodity price levels of the late 1990s, real commodity prices rose for the next 10 years, till 2008, when they stood at over three times their levels of 1998 (Jacks, 2019). Along these lines, researchers investigated the drivers and, in particular, the role of fundamentals versus speculation in driving real commodity prices to such heights (Irwin et al., 2009; Fattouh et al., 2013; Cheng \& Xiong, 2014). A common perspective is that these fluctuations were caused by speculative bubbles due to the phenomenon known as financialization of commodity markets. Many new commodity index funds were established and their activities increased trading volumes and altered the balance of transactions between hedgers and speculators (Masters, 2008; Irwin \& Sanders, 2012a). Robles et al. (2009) argue that the price peak in 2008 was driven by speculation. This viewpoint was also confirmed by some politicians who then called for regulative measures to limit the influence of financial investors on food prices. Adämmer \& Bohl (2017) show that the impact for the European agricultural futures contracts was high during from 2007 to 2009 and lower from 2010 to 2013.The role of speculation has also been discussed from an economic perspective by Sanders et al. (2010) and Sanders \& Irwin (2010), who argue that speculation contributes to price discovery in information efficient markets, provides liquidity to illiquid markets and is a necessary counterpart to hedging activities. Other authors develop theoretical model to study the interaction between the spot and futures commodity markets (Anderson \& Danthine, 1983a, 1983b; Hirshleifer, 1988, 1989; Acharya et al., 2013; Boons et al., 2014; Basak \& Pavlova, 2016; Ekeland et al., 2019; Baker, 2020; Isleimeyyeh, 2020).

However, there are also some recent papers indicating that financialization does not relate to increased commodity price volatility (Brunetti et al., 2011; Buyuksahin \& Harris, 2011; Irwin \& Sanders, 2012b; Aulerich et al., 2014; Kim, 2015; Robe \& Wallen, 2016).

In addition, both rational and irrational speculation can set price trends which may be self- enforced by herd behavior and result in prices bubbles. Brunnermeier (2008) shows four types of price bubbles: (i) a rational bubble model under symmetric information where all market participants are aware of the bubble, but they jointly believe that it continues to grow, so that one can successfully ride the bubble; (ii) the presence of asymmetric information, the finite bubbles exist and traders realize that an asset is overpriced, but believe that it is possible to sell the asset at a higher price before its true value becomes common 
knowledge (Allen, Morris, \& Postlewaite, 1993); (iii) when bubbles arise due to limited arbitrage and less informed traders may push up asset prices in the short term, even if the assets are already overpriced. This noise trader risk deters rational market participants from betting against erroneous beliefs (De Long et al., 1990); (iv) heterogeneous beliefs of traders resulting in overpricing if short-sale constraints are present at the same time. In that case, optimists push up prices while pessimists cannot fully counterbalance (Miller, 1977).

Our paper is inspired by the empirical studies which deal with the importance of various diverse forces influencing commodity price booms and busts. Among them, the first group of papers analyzes the causal relation between financial investors/speculators and commodity prices. Starting with Robles et al (2009), Sanders et al. (2010) who decompose open interest in commodity future markets into commercial and noncommercial positions. They find that speculative activities did not show a significant change during the years analyzed, i.e., speculation was not "excessive". Sanders and Irwin (2010) find a similar result emphasizing no significant relationship between returns in commodity futures markets and long positions held by index funds.

The second group of papers analyses the detection of speculative bubbles in commodity prices. Went et al. (2009), investigating the presence of rational speculative bubbles in twenty-eight commodities traded in the US commodity markets, conclude that eleven of them (including wheat) experienced episodes of rational speculative bubbles. Gilbert (2010) looks for evidence of trend-following behavior in the commodity price process and finds that index-based investment in commodity futures has an impact on the prices of wheat, corn and soybeans and that these investments generated a bubble in futures prices. Liu \& Tang (2010) argue that a bubble exists in futures prices of corn and sugar. They find that spot prices were co-integrated with the convenience yields before 2004, but a structural break occurred in 2004 and since then, prices and convenience yields have sometimes had opposite trends.

Our paper is an extension of Bampinas \& Panagiotidis (2017) who examine the cross-market linkages between stocks and spot and futures oil markets during four crises such as the Mexican "Tequila" crisis in 1994, the Asian "flu" in 1997, the dot.com bubble in 2000 and the global financial crisis. In our work, we empirically investigate the impact in major actively traded commodity prices of three episodes: [i] the rapid increase in commodity prices; [ii] the commodity depression; [iii] and the global financial crisis.

\section{COMMODITY PRICES: SOME SALIENT FEATURES}

The post World War II efforts, in terms of re-industrialization and re-urbanization, in many of European countries, Japan and the later economic transformation of the East Asian tigers, created shocks in commodity demand and shocks in their real prices. In the late 1970s, the early 1980s and the late 1990s, in relation to the global recession of 1974 and 1981 and the Asian financial crisis of 1997, negative commodity demand shocks are evident (see Figure 1). 
FIGURE 1

\section{COMMODITY PRICES SECTOR 1971:1 - 2018:12}

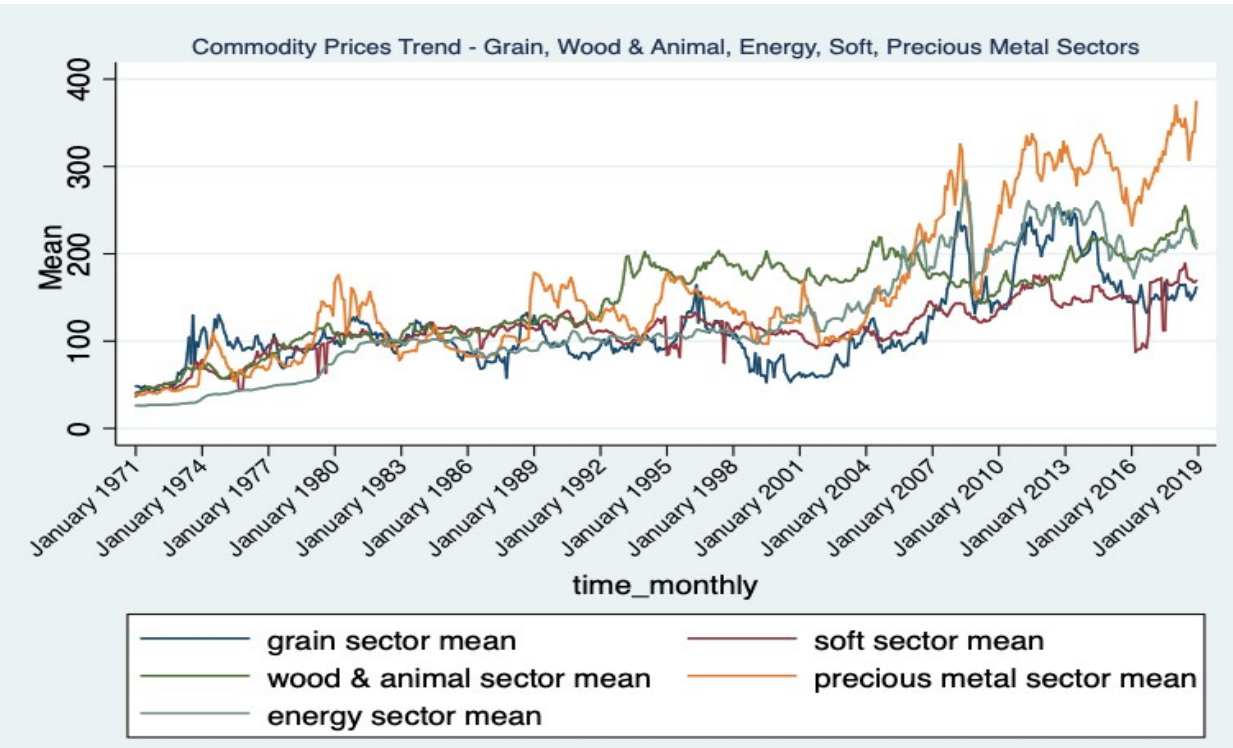

From the late 1990 s and the early 2000 s, due to unexpectedly strong global growth - driven by the industrialization and urbanization of China, there were in turn a series of positive commodity demand shocks. Moreover, the strong effects of the global financial crisis are clearly visible in the series of accumulated effects of commodity demand shocks. Disentangling each commodity sector, such as grain, soft, wood \& animal, precious metal and energy, some interesting results emerge. In particular, the grain sector of agricultural commodity shows a different trend in prices rather the other ones.

FIGURE 2

\section{COMMODITY PRICES GRAIN SECTOR}

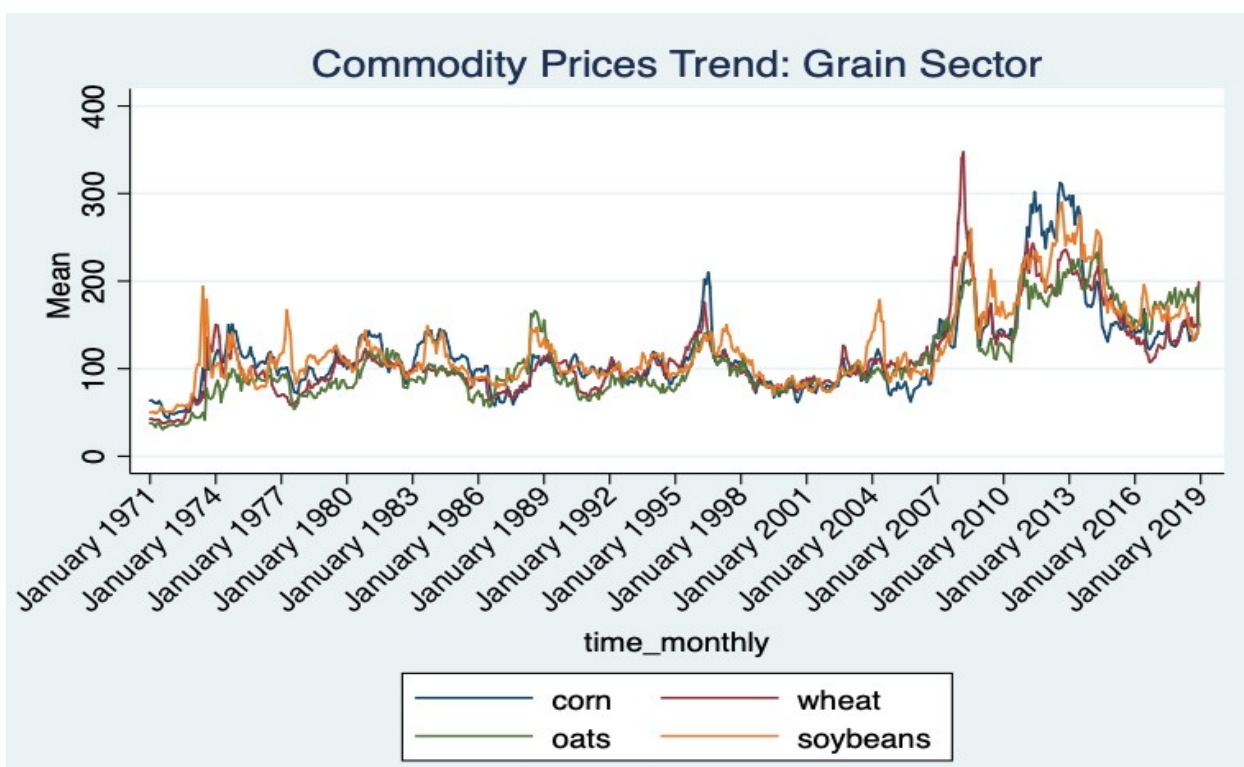


Figure 2 depicts the evolution of the index of monthly prices for agricultural grain commodities sector, e.g., oats, wheat, corn and soybean into broader perspective. There were several short periods $(1980,1983$, 1988 and 1996) when prices increased from the previous year although prices trended slightly downward between 1980 and 2002. In the early 1970s, the unexpected purchase, of a large amount of grain by the Soviet Union, stimulated world demand. The Soviet Union's behavior led many other centrally planned countries to increase grain imports, causing agricultural trade to rise dramatically. Between 1971 and 1972, world exports of wheat increased approximately 29\% (Peters, Langley, \& Westcott, 2009).

After 2001, prices began to rise slowly and by 2004 reached the level that they had been in the mid1980s. In early 2006, commodity grain sector prices began to rise more quickly. During the last ten years, prices of these commodities rose sharply to a new high. From 2013, they decreased dramatically due to the effects of the sub-prime financial and sovereign debt crises. Looking at the trend of the four crops (oats, wheat, corn and soybeans) in Figure 2, in general, the prices rise and recede in a similar way. This could happen because buyers can substitute, among these, the cheaper one. Each period of rapidly rising prices was followed by a retreat back to their pre-spike level.

Four more additions, Figure 3, 4, 5 and 6 provide a broader perspective among the price indexes averaging soft, wood \& animal, precious metal and energy sectors. Figure 3 and 4 show an increased trend in commodity grain sector, in particular, during the last years. In 2011, after reaching a low point in December 2008, the prices of grain commodities rose again, surpassing the 2008 .

FIGURE 3

\section{COMMODITY PRICE SOFT SECTOR}

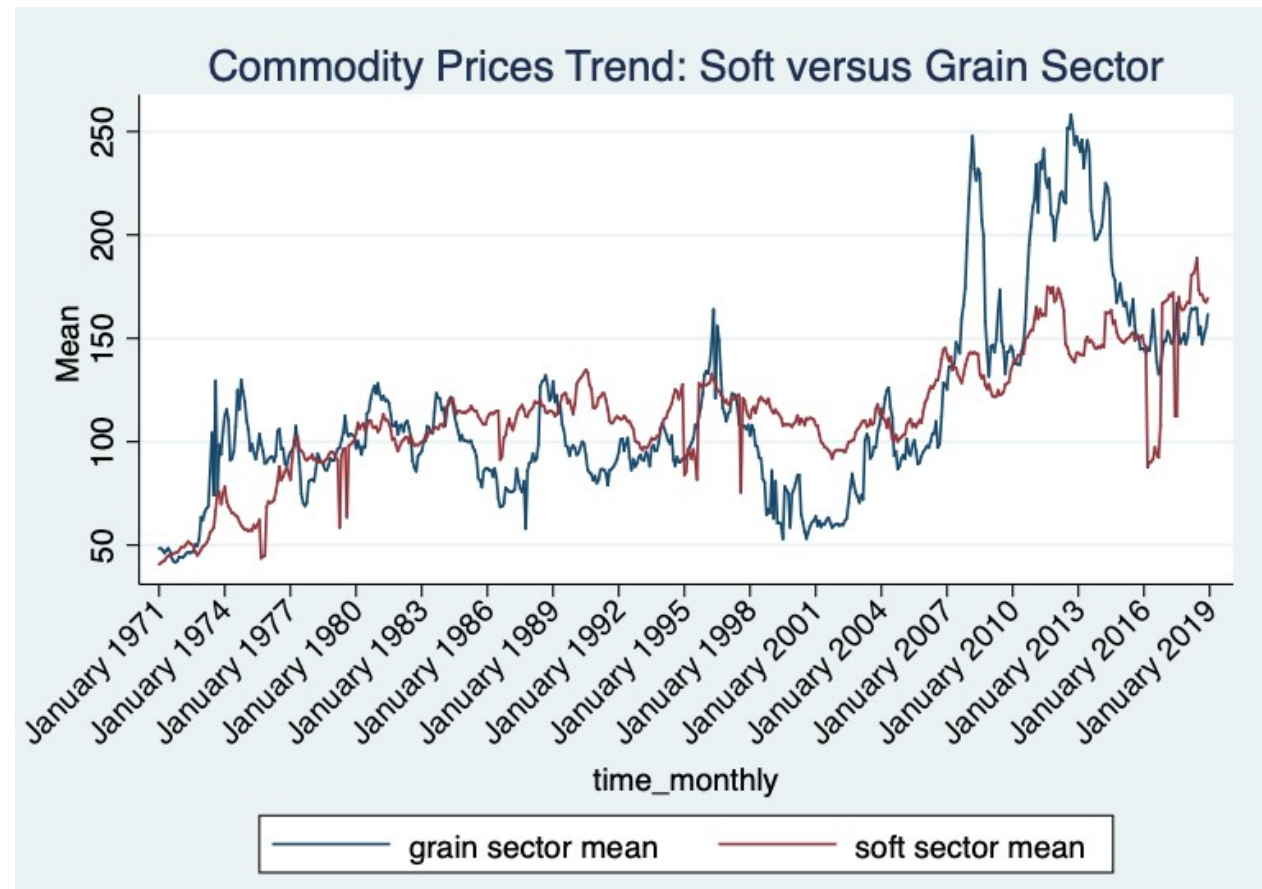

Figure 4 shows how the world per capita meat consumption has been increasing steadily over the last three decades due to the rising global incomes and increased diet diversification, particularly in low- and middle- income countries. 


\section{FIGURE 4}

\section{COMMODITY PRICES WOOD \& ANIMAL SECTOR}

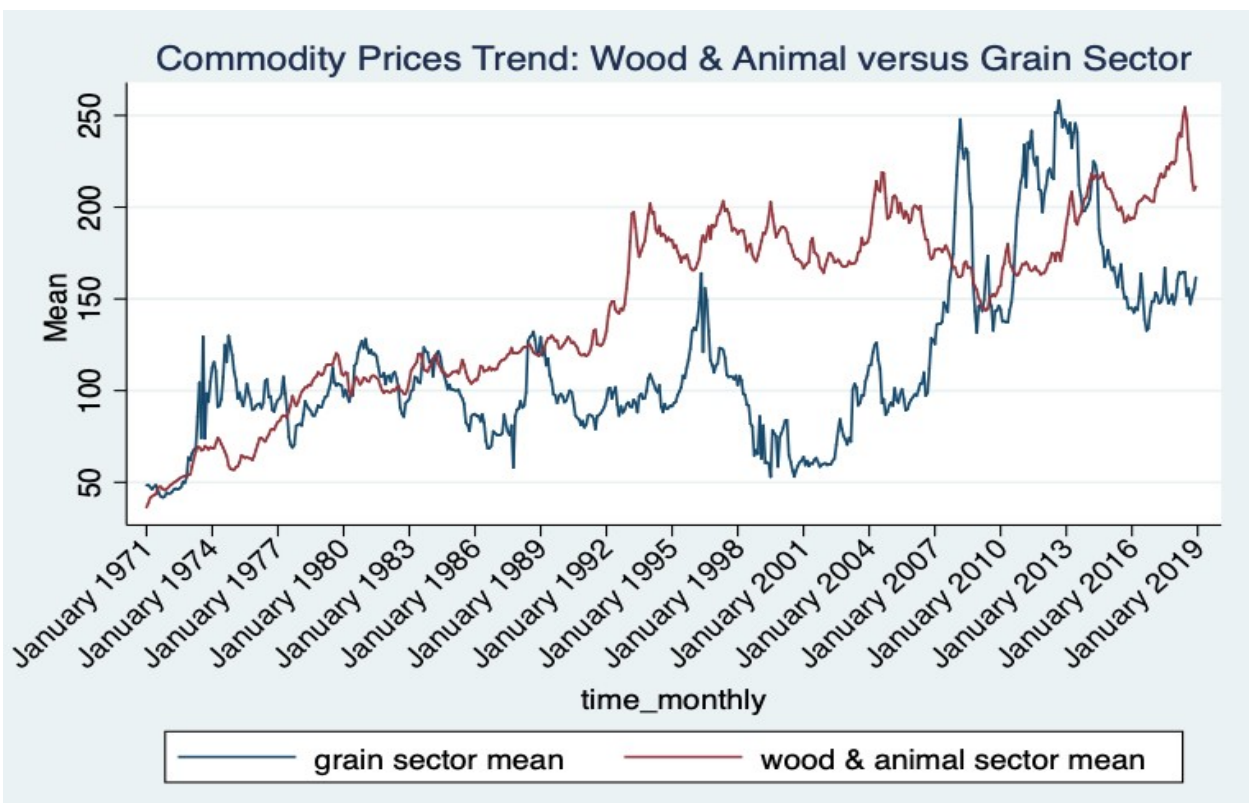

As the demand for meat rises, demand for the grains used to produce meat also increase. Further, some countries have adopted policies to increase self-sufficiency in meat production. However, as the global economic recession deepened in 2008 and 2009, world demand for meat declined.

\section{FIGURE 5}

\section{COMMODITY PRICES PRECIOUS METAL SECTOR}

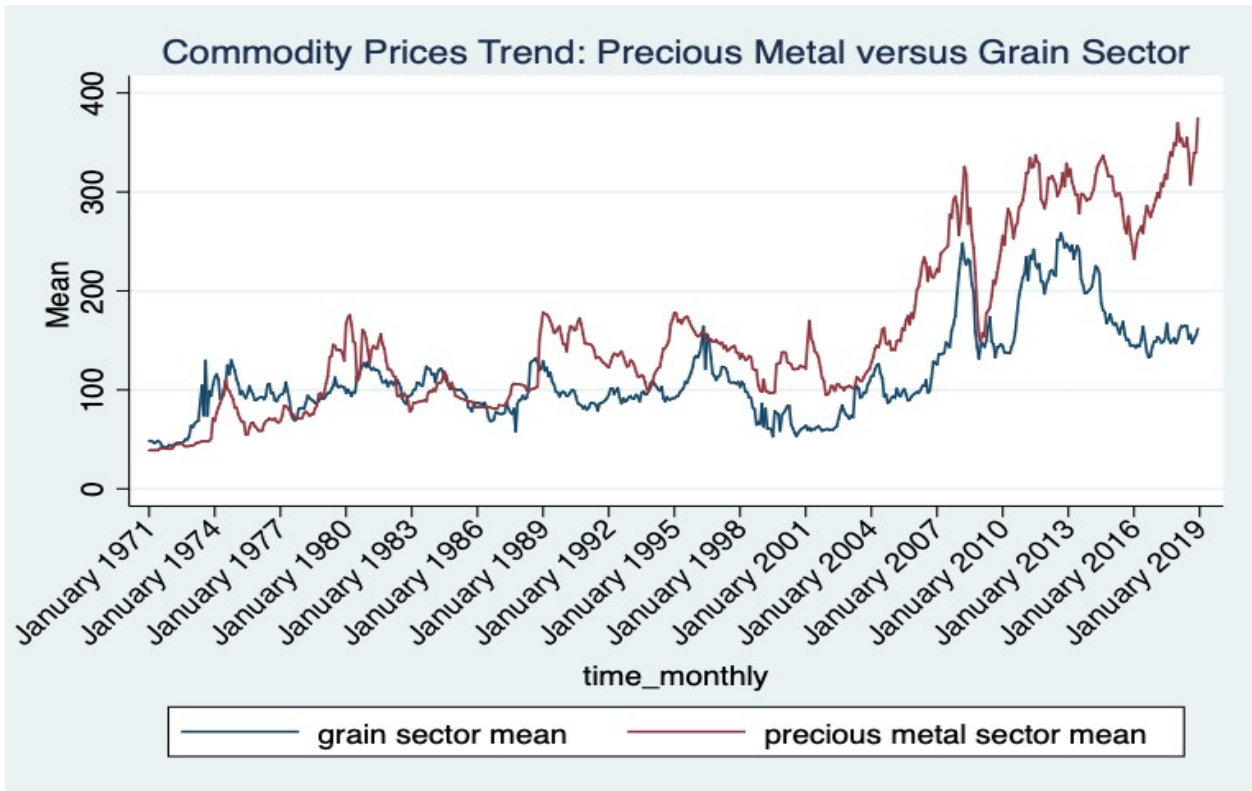

Price indices, for other commodity categories such as, wood \& animal, metal and energy sector have also risen, suggesting that global economy-wide factors contributed to the surge in prices did during 2002- 
2008. After the peak in mid-2008, these price indices declined and, among them, energy and precious metal has risen more that the agricultural commodity price index.

From early 2002 to mid-2008, crude oil prices rose sharply reflecting the crude oil demand caused by robust world economic growth and rapid manufacturing growth in China, India and other Asian countries (see Figure 6). However, the largest increases were from early 2007 to mid-2008, when oil prices more than doubled. Due to the weakening of the global economy, by early 2009 , the decline in demand for petroleum and other sources push down crude oil prices from their earlier peak.

\section{FIGURE 6 COMMODITY PRICES ENERGY SECTOR}

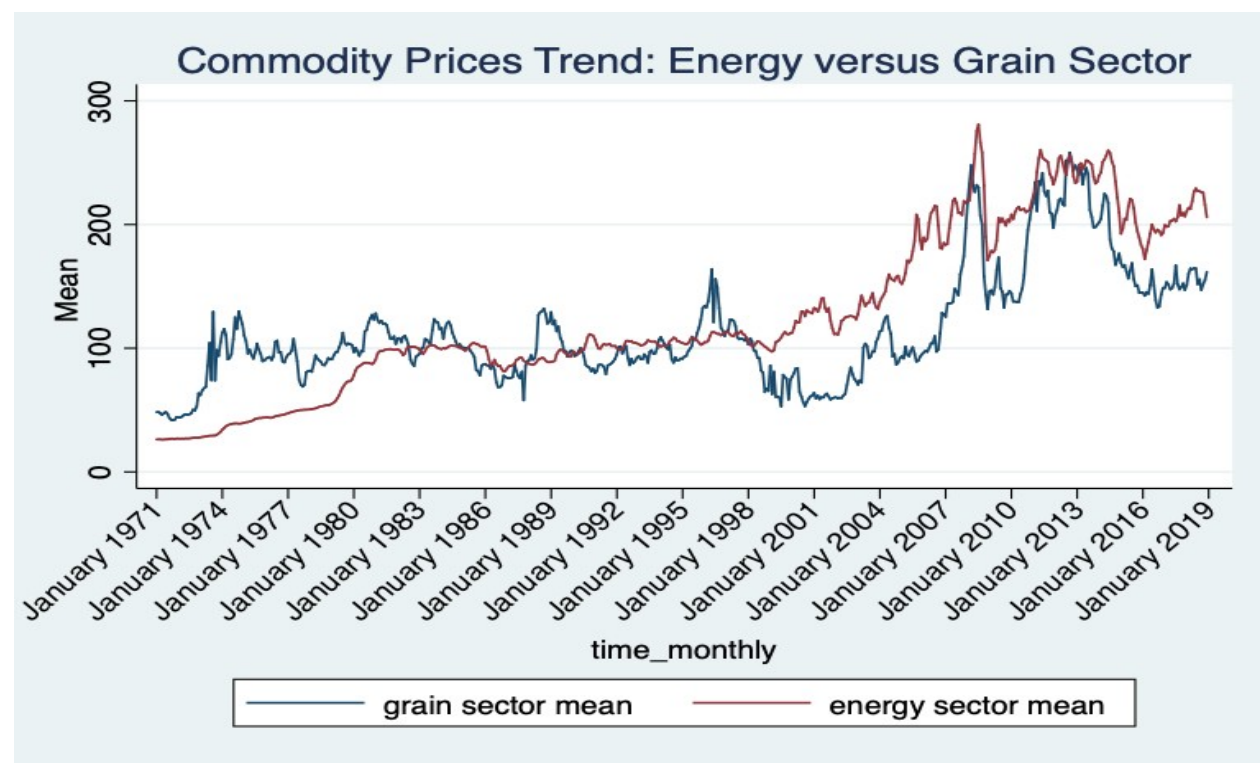

After the 2009 global recession, the economic improvement and was particularly robust in the more energy intensive economies of low- and middle-income countries. This growth increased the demand for energy and the price of crude oil rose sharply even more than food commodity prices.

\section{DATA AND EMPIRICAL STRATEGY}

\section{Data Sample \\ Commodity Prices}

In this study, we consider ten major traded commodities which can be categorized into five subgroups, namely: grains, softs, animals \& woods, precious metals and energy. The price of each commodity covers the time period January 1971:1 to December 2018:12. As in Brooks et al. (2015), we use monthly data mainly because we want to disentangle the bubbly aspects of behavior from the variations caused by microstructure mechanisms in the market that affect higher frequency data. In addition, most of the influential factors, for example, the macroeconomic factors, that we consider into the econometric model, are available on a monthly basis only. Commodities prices and macroeconomic factors are obtained from the Federal Reserve Economic Database (FRED) of the Federal Reserve Bank of St. Louis.

Table 1 presents summary statistics of the major traded agricultural commodity prices. 
TABLE 1

DESCRIPTIVE STATISTICS: AGRICULTURAL COMMODITY PRICES

\begin{tabular}{|l|c|c|c|c|c|c|c|c|}
\hline Commodity & Exchange & Mean & Std. Dev. & Min. & p25 & p50 & p75 & Max. \\
\hline Corn & CBT & 118.75 & 50.17 & 43.20 & 88.00 & 106.65 & 137.55 & 312.30 \\
\hline Wheat & CBT & 113.86 & 45.36 & 37.70 & 86.15 & 103.70 & 128.90 & 347.30 \\
\hline Oats & CBT & 110.72 & 46.14 & 30.80 & 80.80 & 95.10 & 137.30 & 247.00 \\
\hline Soybeans & CBT & 123.89 & 46.81 & 48.80 & 93.80 & 108.00 & 144.80 & 289.80 \\
\hline
\end{tabular}

The table reports summary statistics of the agricultural commodity prices over the period 1stJanuary 1971 to December 31 st 2018.

Table 2 presents summary statistics of the other major traded commodity prices. These commodities belong to the Soft sector (e.g., orange juice, cotton and coffee), the Wood \& Animal sector (e.g., lumber), the Precious metal sector (e.g., silver, gold) and the Energy sector (e.g., crude oil, heating oil, natural gas).

TABLE 2

DESCRIPTIVE STATISTICS: SOFT, WOOD \& ANIMAL, PRECIOUS METAL, ENERGY SECTORS

\begin{tabular}{|l|c|c|c|c|c|c|c|c|}
\hline \multicolumn{1}{|c|}{ Commodity } & Exchange & Mean & Std. Dev. & Min. & p25 & p50 & p75 & Max. \\
\hline Orange juice & ICE & 115.97 & 44.06 & 35.30 & 96.05 & 109.05 & 139.15 & 255.50 \\
\hline Cotton & ICE & 102.31 & 24.62 & 42.90 & 86.50 & 101.55 & 119.40 & 181.40 \\
\hline Coffee & ICE & 124.31 & 36.26 & 44.00 & 109.10 & 130.60 & 145.70 & 179.70 \\
\hline Lumber & CME & 146.22 & 48.95 & 36.40 & 109.40 & 164.00 & 185.50 & 254.50 \\
\hline Gold, Silver & Comex & 157.36 & 84.84 & 38.90 & 96.90 & 135.05 & 198.10 & 374.50 \\
\hline $\begin{array}{l}\text { Crude oil, } \\
\text { Natural Gas and } \\
\text { Heating oil }\end{array}$ & NYMEX & 126.16 & 65.09 & 26.10 & 89.55 & 104.95 & 186.50 & 280.83 \\
\hline
\end{tabular}

The table reports summary statistics of the Soft, Wood \& Animal, Precious metal and Energy sector commodity prices over the period 1stJanuary 1971 to December 31 st2018.

Comparing Table 1 with Table 2, the major traded agricultural commodities show a higher volatility (in terms of standard deviation) with respect soft commodity sector composed of orange juice, cotton and coffee. In particular, among the grain commodity sector, corn is the most highly volatile and wheat the least. This high volatility is also explained by the increased involvement by the hedge funds, index funds and sovereign wealth funds in the agricultural future markets. Particularly from 2005, the share of open interest (i.e., the total number of contracts) held by funds in the future market for agricultural commodities doubled. The investors used commodities as an asset class to diversify their financial portfolios rather than being interested in the underlying agricultural commodities. Therefore, these investors had primarily a financial interest in the markets (Trostle, 2011).

\section{Macroeconomic Factors}

The following macro-economic variables are used for the empirical study as factors tighten up commodity prices. 
TABLE 3

DESCRIPTIVE STATISTICS OF MACROECONOMIC FACTORS

\begin{tabular}{|l|r|r|r|r|r|r|r|}
\hline \multicolumn{1}{|c|}{ Macroeconomic Factors } & Mean & $\begin{array}{c}\text { Std. } \\
\text { Dev. }\end{array}$ & Min. & p25 & p50 & p75 & Max. \\
\hline Industrial Production & 75.11 & 22.38 & 38.53 & 53.24 & 73.3 & 96.35 & 110.55 \\
\hline Housing Starts & $1,434.82$ & 431.82 & 478 & $1,142.00$ & $1,467.00$ & $1,719.00$ & $2,494.00$ \\
\hline $\begin{array}{l}\text { Real Personal Consumption } \\
\text { Expenditures }\end{array}$ & 0.25 & 0.50 & -2.50 & 0.00 & 0.25 & 0.50 & 2.40 \\
\hline 3-Month Treasury Bill Yield & 4.66 & 3.43 & 0.01 & 1.67 & 4.89 & 6.46 & 16.30 \\
\hline
\end{tabular}

The table reports summary statistics of the macroeconomic factors over the period $1^{\text {st January }} 1971$ to December

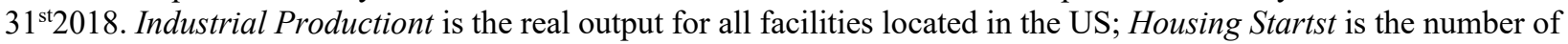
privately-owned new houses on which construction has been started in a given period; Real Personalt is the actual and imputed expenditures of households and is a proxy of the value of goods and services consumed by individuals; Three Month Treasury Bill Yieldt is the discount yield of 3M T-Bills in the secondary market.

The data are obtain from the Federal Reserve Economic Database (FRED) of the Federal Reserve Bank of St. Louis: Industrial Production (Final Products): is the real output for all facilities located in the US; Housing Starts (Total: New Privately Owned Housing Units Started): is the number of privately owned new houses on which construction has been started in a given period; Real Personal Consumption Expenditures: is the actual and imputed expenditures of households and is a proxy of the value of goods and services consumed by individuals; 3-Month Treasury Bill Yield (Secondary Market Rate): is the discount yield of 3M T-Bills in the secondary market. Table 3 shows their main descriptive statistics.

\section{Empirical Strategy}

We use a time series regression model to investigate the impact on major actively traded agricultural commodity by three financial crises between 1971:1 and 2018:12. In particular, we identify: [i] the episode that peaked in 1974; [ii] the commodities depression in the 1990s; [iii] the credit crunch and sovereign debt crisis in the 2000s. For each of them, we create three dummy variables which takes the value 1 in relation to:

1. the rapid increase in commodity prices during the 1970s: January 1971 to December 1979;

2. the commodities depression in the 1990s: January 1990 to December 1999;

3. the credit crunch and sovereign debt crisis: January 2008 to December 2011.

We estimate the following econometric model:

Commodity Price $_{t}=\alpha+\beta_{1}$ Rapid Increase $1970 s_{t}+\beta_{2}$ Commodity Depression $_{t}+$ $\beta_{3}$ Credit Crunch \& Debt Crisis $t_{t}+\gamma_{1} H S_{t}+\gamma_{2} I P_{t}+\gamma_{3} R P C_{t}+\gamma_{4} T-$ Bill $_{t}+\varepsilon_{t}$

where Rapid Increase1970st is the first dummy variable related to the rapid increase in commodity prices during the 1970s which takes value one from 1971:1 to 1979:12, zero otherwise; Commodity Depression ${ }_{t}$ is the second dummy variable related to the commodity depression during the 1990s which takes value one from 1990:1 to 1999:12, zero otherwise; Credit Crunch \& Debt Crisis $s_{t}$ is the third dummy variable related to the credit crunch and sovereign debt crisis occurred from 2008 to 2011 which takes value one from 2008:1 to 2011:12 and zero otherwise. As control variable, we consider the following macroeconomic factors: Industrial $l_{t}$ is the real output for all facilities located in the US; Housing Starts $t$ is the number of privately owned new houses on which construction has been started in a given period; Real Personal ${ }_{t}$ is the actual and imputed expenditures of households and is a proxy of the value of goods and services consumed by individuals; Three - Month Treasury Bill Yield is $_{\text {in }}$ the discount yield of 3M T-Bills in the secondary market. 


\section{EMPIRICAL RESULTS}

Table 4 confirms the main effects of the three episodes on each agricultural commodity price. During the rapid increase in 1970s, all the major agricultural commodity prices were positively influenced by a series of events, including the Soviet Union's unexpected purchase of large amounts of grain on the global markets. The empirical evidences are also statistically significant emphasizing how many other centrally planned countries, after the decision of the Soviet Unions, decided to increase grain imports, causing world agricultural trade to rise dramatically. Between 1971 and 1972, the world exports of wheat increased nearly 29\% (Peters et al., 2009).

Another episode, which explains the rapid increase in prices, is the persistent depreciation of the U.S. dollar against other major currencies. The United States, to defend the dollar's fixed exchange rate from the insufficient gold reserves, removed the dollar from the gold standard to a floating exchange rate. As a consequence, the U.S. products began more competitive and both exports and prices rose. In 1972, the adverse weather conditions caused a declined in the world (United States, Australia, Canada, and Soviet Union) grain production: as a result wheat, corn and soybeans prices soared in 1973 and 1974. In addition, the tight global market conditions were caused by some policy actions such as export taxes, restrictions and bans undertaken by many countries to cover their domestic markets from global grain and oilseed price increases.

TABLE 4

BASELINE REGRESSIONS: AGRICULTURAL COMMODITY PRICES

\begin{tabular}{|c|c|c|c|c|}
\hline \multirow[t]{2}{*}{ Panel A } & Model (1) & Model (2) & Model (3) & Model (4) \\
\hline & Corn & Wheat & Oats & Soybeans \\
\hline \multirow[t]{2}{*}{ Rapid Increase 1970s } & $16.0767 * * *$ & $19.0411 * * *$ & $4.9649^{*}$ & $14.5487 * * *$ \\
\hline & $(4.108)$ & $(3.172)$ & $(2.934)$ & $(4.219)$ \\
\hline \multirow[t]{2}{*}{ Commodity Depression } & $-19.4050 * * *$ & $-14.0384 * * *$ & $-30.1179 * * *$ & $-23.2763 * * *$ \\
\hline & $(3.643)$ & $(2.704)$ & $(2.432)$ & $-2.714)$ \\
\hline \multirow[t]{2}{*}{ Credit Crunch \& Sovereign Debt } & 8.3802 & $21.3942 * *$ & $-23.2578 * * *$ & 5.0394 \\
\hline & $(10.645)$ & $(9.808)$ & $(6.266)$ & $(7.608)$ \\
\hline \multirow[t]{2}{*}{ Housing Starts } & $-0.0681 * * *$ & $-0.0501 * * *$ & $-0.0579 * * *$ & $-0.0551 * * *$ \\
\hline & $(0.005)$ & $(0.003)$ & $(0.003)$ & $(0.005)$ \\
\hline \multirow[t]{2}{*}{ Industrial Production } & $0.6188 * * *$ & $1.1741 * * *$ & $1.1073 * * *$ & $0.7567 * * *$ \\
\hline & $(0.097)$ & -0.1 & $(0.077)$ & $(0.095)$ \\
\hline \multirow[t]{2}{*}{ Real Personal Consumption } & -1.1089 & $(2.2504)$ & 1.7741 & -2.3479 \\
\hline & $(2.668)$ & $(2.129)$ & $(2.076)$ & $(2.636)$ \\
\hline \multirow[t]{2}{*}{3 Month Treausry Bill } & -0.1742 & $1.4752 * * *$ & -0.0165 & $-1.2401 * *$ \\
\hline & $(0.62)$ & $(.525)$ & $(.417)$ & $(.580)$ \\
\hline \multirow[t]{2}{*}{ Constant } & $171.4451 * * *$ & $88.8293 * * *$ & $115.8593 * * *$ & $154.0672 * * *$ \\
\hline & $(14.60)$ & $(12.831)$ & $(9.362)$ & (13.094) \\
\hline N. Obs. & 576 & 576 & 576 & 575 \\
\hline$R^{2}$ Adjusted & 0.51 & 0.64 & 0.72 & 0.57 \\
\hline F-Test & $62.4 * * *$ & $113.74 * * *$ & $239.56^{* * *}$ & $87.64 * * *$ \\
\hline
\end{tabular}


The table reports the results of the baseline regressions based on agricultural commodity prices over the period $1^{\text {st } J a n u a r y} 1971$ to December $31^{s t} 2018$. RapidIncrease $1970 s_{t}$ is the first dummy variable related to the rapide increase in commodity prices during the 1970s which takes value one from 1971:1 to 1979:12, zero otherwise; Commodity Depression $_{t}$ is the second dummy variable related to the commodity depression during the 1990s which takes value one from 1990:1 to 1999:12, zero otherwise; Credit Crunch \& Debt Crisis $s_{t}$ is the third dummy variable related to the credit crunch and sovereign debt crisis occured from 2008 to 2011 which takes value one from 2008:1 to 2011:12 and zero otherwise. Industrial Production $_{t}$ is the real output for all facilities located in the US; Housing Starts $s_{t}$ is the number of privately-owned new houses on which construction has been started in a given period; Real Personal is the actual and imputed expenditures of households and is a proxy of the value of goods and services consumed by individuals; Three Month Treasury Bill Yield is $_{\text {in }}$ the discount yield of $3 \mathrm{M}$ T-Bills in the secondary market.

Source: Authors' data elaboration from Federal Reserve Economic Database (FRED) of the Federal Reserve Bank of St. Louis.

$* * *, * *, *$, denote $1 \%, 5 \%, 10 \%$ statistical significance respectively

During the Commodity Depression time period, a common negative relationship is shown by all the agricultural commodities. This decline caused global demand to fall. In 1994-96, global production of grains fell for some consecutives years due to below-normal harvests in the major grain-exporting countries. As in the 1970s, the impact of declining production on prices in the 1990s was compounded by the decisions of some countries, including the United States, to reduce carryover stocks and idle cropland to support prices (Peters et al., 2009).

During previous periods of price increases, markets adjusted leading to prices declined. However, in contrast to the $1970 \mathrm{~s}$, the countries response to price spikes were mitigated, particularly because the short duration of the price increases (only 2 years, from 1994 to 1996). In addition, lower levels of inflation were not severe on consumer budgets. Moreover, trade liberalization also helped make agricultural commodity markets more flexible to changes in global supply and demand conditions.

In the third episode considered we consider, i.e., Credit Crunch \& Sovereign Debt, the U.S. dollar had started to strengthen against other major currencies. High prices for many crops encouraged increased plantings in 2008 and some land enrolled in the Federal Conservation Reserve Program has become available for production as contracts expired. These and other ongoing adjustments placed downward pressure on prices.

During this third episode, the situation is similar to that in the mid-1990s, when a decrease in crop prices was caused by the Asian financial crisis. However, the global financial crisis originated in more developed countries, such as the United States and Europe. The length and the severity of the recent global economic slowdown explain the price retreat. As agricultural markets adjust in this weakened economic environment, price behavior may continue to be volatile. The Credit Crunch \& Sovereign Debt shows a positive and statistically significant impact for only the wheat commodity whereas the oats show a negative relationship. The underlying economic intuition relies on the fact that the financial and economic structure in the agricultural sector was different than in the past and policy options and actions have changed as well. The recent global financial crisis was so huge and engaged so many countries in the world that their effects could be different in relation to different commodity prices. Moreover, the impact of the credit crunch and the sovereign debt on the agricultural commodity prices is also associated with the increased involvement of the hedge funds, index funds and sovereign wealth funds in the agricultural futures markets. Particularly from 2005, the share of open interest (i.e., the total number of contracts) held by funds in the future market for agricultural commodities doubled. The investors used commodities as an asset class to diversify their financial portfolios rather than being interested in the agricultural commodities. Therefore, these investors had primarily a financial interest in the markets (Trostle, 2011), and as noted in Caballero et al. (2008), lower performances in stock markets lead investors to redirect investment strategies into commodities.

Table 5 shows the main effects of the three episodes, with macroeconomic factors, on each commodity sector. The dependent variable is the mean of the prices of each commodity for the relative sector. 
TABLE 5

REGRESSIONS FOR ALL THE COMMODITY SECTORS

\begin{tabular}{|c|c|c|c|c|c|}
\hline Panel B & $\begin{array}{l}\text { Model (1) } \\
\text { Grain }\end{array}$ & $\frac{\text { Model (2) }}{\text { Soft }}$ & $\begin{array}{c}\text { Model (3) } \\
\text { Wood \& } \\
\text { Animal } \\
\end{array}$ & $\begin{array}{c}\text { Model (4) } \\
\text { Precious } \\
\text { Metal } \\
\end{array}$ & $\begin{array}{c}\text { Model (5) } \\
\text { Energy }\end{array}$ \\
\hline Rapid Increase 1970s & $\begin{array}{r}14.2892 * * * \\
(3.352)\end{array}$ & $\begin{array}{r}-21.4376^{* * * *} \\
(2.501)\end{array}$ & $\begin{array}{r}-18.1195^{* * * *} \\
(2.367)\end{array}$ & $\begin{array}{r}26.2235 * * * \\
(5.196)\end{array}$ & $\begin{array}{r}-25.2048^{* * * *} \\
(2.836)\end{array}$ \\
\hline Commodity Depression & $\begin{array}{r}-21.8308 * * * \\
(2.845)\end{array}$ & $\begin{array}{r}-4.0079 * * * \\
(1.504)\end{array}$ & $\begin{array}{r}22.7854 * * * \\
(1.781)\end{array}$ & $\begin{array}{r}-27.6901 * * * \\
(3.519)\end{array}$ & $\begin{array}{r}-32.3256^{* * * *} \\
(1.753)\end{array}$ \\
\hline $\begin{array}{l}\text { Credit Crunch \& } \\
\text { Sovereign Debt }\end{array}$ & $\begin{array}{l}3.5554 \\
(7.955)\end{array}$ & $\begin{array}{l}1.0542 \\
(3.162)\end{array}$ & $\begin{array}{r}-21.5376 * * * \\
(2.266)\end{array}$ & $-27.1958 * * *$ & $\begin{array}{r}11.9507 * * \\
(4.915)\end{array}$ \\
\hline Housing Starts & $\begin{array}{r}-0.0610 * * * \\
(0.004)\end{array}$ & $\begin{array}{r}-0.0195 * * * \\
(0.002)\end{array}$ & $\begin{array}{r}0.0016 \\
(0.002)\end{array}$ & $\begin{array}{r}-0.0959 * * * \\
(0.005)\end{array}$ & $\begin{array}{r}-0.0388 * * * \\
(0.003)\end{array}$ \\
\hline Industrial Production & $\begin{array}{r}0.8313 * * * \\
(0.090)\end{array}$ & $\begin{array}{r}0.7013^{* * * *} \\
(0.051)\end{array}$ & $\begin{array}{r}1.8941^{* * * *} \\
(0.063)\end{array}$ & $\begin{array}{r}2.9184 * * * \\
(0.137)\end{array}$ & $\begin{array}{r}1.8607 * * * \\
(0.073)\end{array}$ \\
\hline $\begin{array}{l}\text { Real Personal } \\
\text { Consumption }\end{array}$ & -0.9174 & 0.8384 & 1.0594 & -0.4231 & -0.0821 \\
\hline 3 Month Treausry Bill & $\begin{array}{l}-0.0962 \\
(-0.533)\end{array}$ & $\begin{array}{r}0.9558 * * * \\
(0.281)\end{array}$ & $\begin{array}{r}0.0517 \\
(0.323)\end{array}$ & $\begin{array}{r}1.9159 * * * \\
(0.728)\end{array}$ & $\begin{array}{r}-1.2039 * * * \\
(0.379)\end{array}$ \\
\hline Constant & $\begin{array}{r}141.9518^{* * *} \\
(12.091)\end{array}$ & $\begin{array}{r}87.8609 * * * \\
(5.724)\end{array}$ & $\begin{array}{l}1.5438 \\
(6.816)\end{array}$ & $\begin{array}{r}70.4494 * * * \\
(14.890)\end{array}$ & $\begin{array}{r}58.2382 * * * \\
(9.117)\end{array}$ \\
\hline N. Obs. & 576 & 576 & 576 & 572 & 576 \\
\hline $\begin{array}{l}R^{2} \text { Adjusted } \\
\text { F-Test }\end{array}$ & $\begin{array}{r}0.62 \\
109.1524 * * *\end{array}$ & $\begin{array}{r}0.70 \\
173.6715^{* * *}\end{array}$ & $\begin{array}{r}0.91 \\
1075.642 * * *\end{array}$ & $\begin{array}{r}0.80 \\
328.3508 * * * \\
\end{array}$ & $\begin{array}{r}0.91 \\
850.1105^{* * *} \\
\end{array}$ \\
\hline 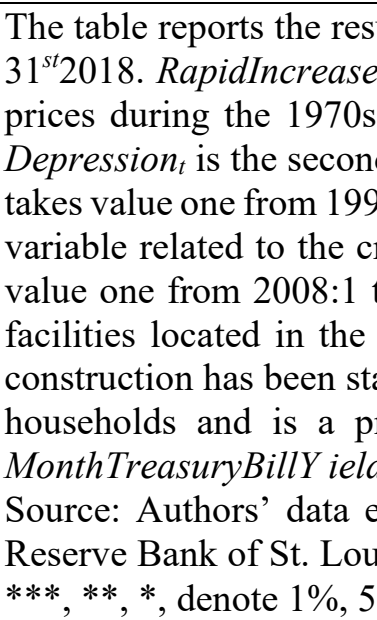 & $\begin{array}{l}\text { for all the con } \\
\text { St is the first } \\
\text { ch takes valu } \\
\text { mmy variable } \\
\text { o } 1999: 12 \text {, ze } \\
\text { crunch and s } \\
11: 12 \text { and ze } \\
\text { Housing Star } \\
\text { in a given pe } \\
\text { of the value } \\
\text { he discount y } \\
\text { ration from F }\end{array}$ & $\begin{array}{l}\text { modity sector } \\
\text { lummy variab } \\
\text { one from } 19 \\
\text { related to the } \\
\text { o otherwise; } C \\
\text { vereign debt } \\
\text { o otherwise. I } \\
s_{t} \text { is the num } \\
\text { iod; RealPers } \\
\text { of goods an } \\
\text { eld of 3M T-B } \\
\text { ederal Reserv }\end{array}$ & $\begin{array}{l}\text { ver the perio } \\
\text { related to th } \\
: 1 \text { to } 1979: 1 \\
\text { nmodity dep } \\
\text { dit Crunch \& } \\
\text { sis occured } \\
\text { ustrial Prod } \\
\text { of privately } \\
\text { al } \text { is the actu } \\
\text { services co } \\
\text { S in the secol } \\
\text { Economic D } \\
\text { ectively. }\end{array}$ & $\begin{array}{l}{ }^{s t} \text { January } 19 \\
\text { pide increas } \\
\text { zero otherw } \\
\text { sion during } \mathrm{t} \\
\text { bt Crisis } \text { is }_{\mathrm{t}} \\
\mathrm{n} 2008 \text { to } 20 \\
\text { ion } \text { is the re } \\
\text { wned new h } \\
\text { and imputed } \\
\text { med by ind } \\
\text { ry market. } \\
\text { pase (FRED) }\end{array}$ & $\begin{array}{l}\text { to December } \\
\text { in commodity } \\
\text { e; Commodity } \\
\text { e 1990s which } \\
\text { third dummy } \\
1 \text { which takes } \\
\text { output for all } \\
\text { ises on which } \\
\text { xpenditures of } \\
\text { iduals; Three } \\
\text { of the Federal }\end{array}$ \\
\hline
\end{tabular}

The empirical results show the different impacts of the three episodes on each commodity sector. The grain sector shows the same relationship as stated in Table 4. The same features are presented by the precious metal sector with a strong and highly statically significant relationship between the credit crunch $\&$ sovereign debt crisis. However, these results do not consider the potential correlation among commodities. In particular, the correlation between energy and food. Energy prices play a key role in the determination of food prices. And the post-2006 boom of food prices was partly driven by higher energy 
costs. These findings strengthen the cross-market linkages between the stock and crude oil markets after the financialization of commodities in early 2003 (Tang \& Xiong, 2012; Bampinas \& Panagiotidis, 2017). In addition, the impact of the vast inflows from commodity index investors materialized after 2008 (Adams \& Glück, 2015).

Moreover, agriculture is energy intensive and fuel plays a crucial role and is a key cost component of producing and transporting food commodities such as wheat, rice soybeans. Therefore, the impact of lower energy prices plays a role in lowering prices in agricultural sec- tor. Another important implication is related to the effects captured by the Credit Crunch \& Sovereign Debt. The different relationships show how each commodity sector could also be affected by exchange rates movements, GDP and the consequences of monetary policy instruments used by the major central banks to overcome the global financial crisis.

During 2006 and 2008, the demand for food commodities in China, Brazil, Mexico, India, and countries of Southeast Asia and Central America has grown as consumers have diversified their diets by including more vegetable oils, meat, and dairy products. Figure 7 summarizes the factors that have contributed to the sharp increase in food commodity prices from the 1990s.

\section{FIGURE 7 \\ FACTORS CONTRIBUTING TO AGRICULTURAL COMMODITIES INCREASE}

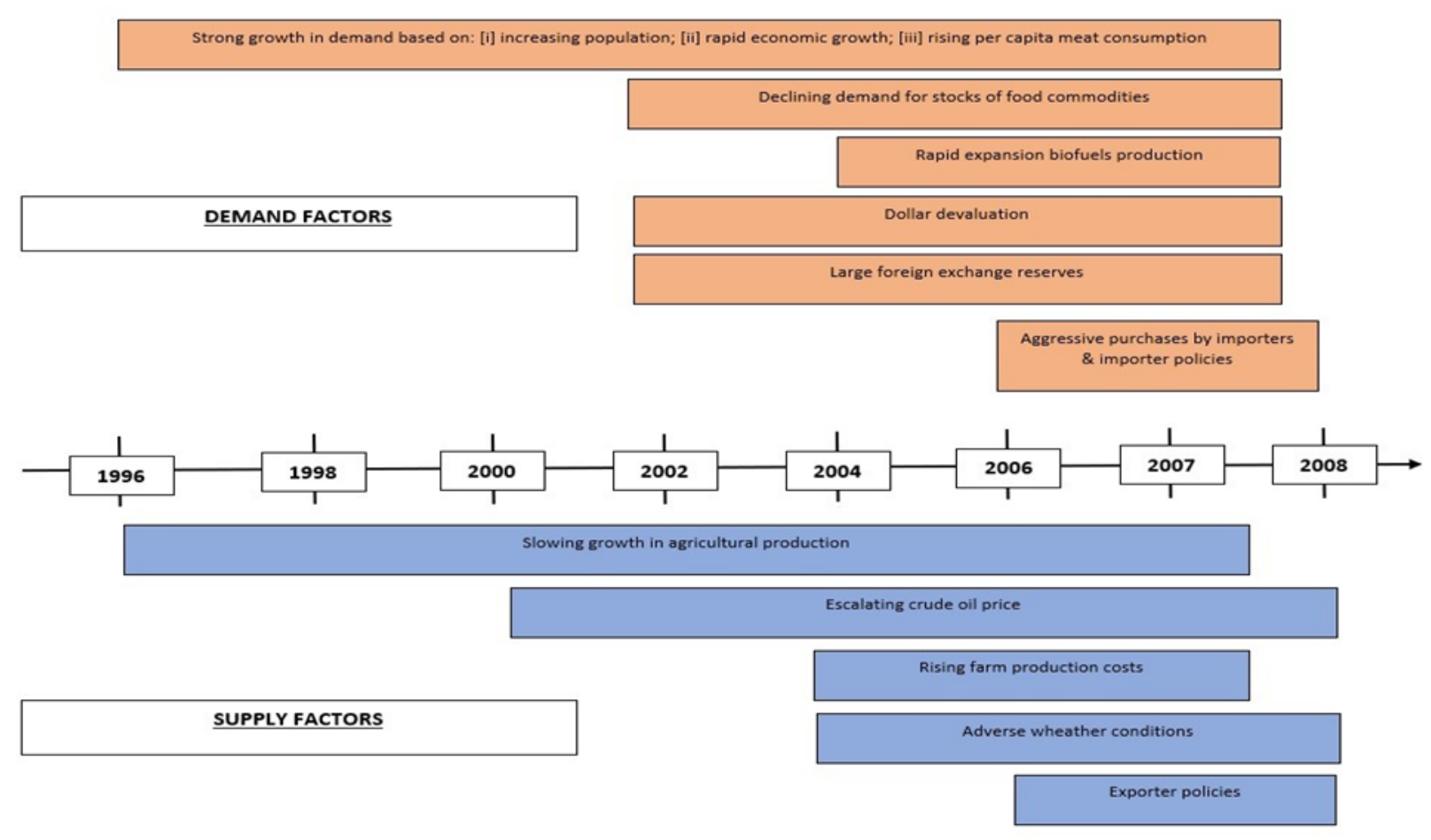

Source: Authors' data elaboration from United States Department of Agricultural (May, 2008)

A rapid expansion in demand and a lower growth in production started in the 1990s till 2000s. After that, the rise in crude oil and biofuel prices gave incentives to expand biofuel production. In addition, the devaluation of U.S. dollars enabled some countries to increase food commodity imports. As regards supply side, the rise of energy prices, production costs and, in 2006 and 2007, the adverse weather conditions reduced global production of grains and oilseeds.

Both demand and supply factors resulted in declining global stock and use for grains and oilseeds which, by 2007, fell to the lowest levels since 1970. At the end of 2007 and at the beginning of 2008, many exporters of food commodities imposed restriction on exports due to moderate domestic food price inflation. All these actions represented a prelude for the further increases in food prices in 2007 and 2008. 


\section{CONCLUSIONS}

In this study, we investigated the cross-market linkages that caused the price booms in the major traded agricultural commodity prices during the 1971:1 and 2018:12 time frame divided into three episodes: [i] the rapid price increases during the 1970's; [ii] the commodity depression of the 1990's; and [iii] the credit crunch and sovereign debt crisis in the 2000's.

We investigated the main effects of the three episodes for each of the following commodities: grain, soft, wood \& animal, precious metal and energy sector. On average, the grain sector shows the same relationship emphasized for each subcategory (oats, wheat, corn and soybeans): a positive relationship during the 1970s, and a negative impact during the commodity depression. The credit crunch $\&$ sovereign debt crisis presents a mixed effect between wheat and oat price commodities. As regards precious metal sector, we find a strong and highly statistically significant relationship between the credit crunch \& sovereign debt crisis. We also find the key role played by energy prices as determinants of food prices which strengthen the cross-market linkages between the stock and crude oil markets after the financialization of commodities.

In this paper we have extended the published work of Bampinas \& Panagiotidis (2017). Our investigation to test for influencers leading to booms in agricultural commodity prices, cross linkages in actively traded commodities, over the past 40 years, has given rich dividends. Among these dividends, we explore in another paper, connections of Granger causality between spot and futures prices. We focus on corn, soybeans and wheat that have a global price sensitive market, allowing for extensive opportunities of financialization.

\section{REFERENCES}

Acharya, V.V., Lochstoer, L.A., \& Ramadorai, T. (2013). Limits to arbitrage and hedging: Evidence from commodity markets. Journal of Financial Economics, 109(2), 441-465.

Adämmer, P., \& Bohl, M.T. (2018). Price discovery dynamics in European agricultural markets. Journal of Futures Markets, 38(5), 549-562.

Adams, Z., \& Glück, T. (2015). Financialization in commodity markets: A passing trend or the new normal? Journal of Banking \& Finance, 60, 93-111.

Allen, F., Morris, S., \& Postlewaite, A. (1993). Finite bubbles with short sale constraints and asymmetric information. Journal of Economic Theory, 61(2), 206-229.

Anderson, R.W., \& Danthine, J-P. (1983a). Hedger diversity in futures markets. The Economic Journal, 93(370), 370-389.

Anderson, R.W., \& Danthine, J-P. (1983b). The time pattern of hedging and the volatility of futures prices. The Review of Economic Studies, pp. 249-266.

Aulerich, N.M., Irwin, S.H., \& Garcia, P. (2014). Bubbles, food prices, and speculation: Evidence from the cftc's daily large trader data files. In The economics of food price volatility (pp. 211-253). University of Chicago Press.

Baig, T., \& Goldfajn, I. (1999). Financial market contagion in the Asian crisis. IMF Staff Papers, 46(2), $167-195$.

Baker, S.D. (2020). The financialization of storable commodities. Management Science.

Bampinas, G., \& Panagiotidis, T. (2017). Oil and stock markets before and after financial crises: A local gaussian correlation approach. Journal of Futures Markets, 37(12), 1179-1204.

Basak, S., \& Pavlova, A. (2016). A model of financialization of commodities. The Journal of Finance, 71(4), 1511-1556.

Bernanke, B. (2006). Energy and the economy. Remarks at the economic club of Chicago.

Boons, M., De Roon, F., \& Szymanowska, M. (2014). The price of commodity risk in stock and futures markets. In Afa 2012 Chicago meetings paper.

Brooks, C., Prokopczuk, M., \& Wu, Y. (2015). Booms and busts in commodity markets: Bubbles or fundamentals? Journal of Futures Markets, 35(10), 916-938. 
Brunetti, C., Buyuksahin, B., \& Harris, J.H. (2011). Speculators, prices and market volatility. Available at SSRN 1736737.

Brunnermeier, M.K. (2008). Bubbles. The New Palgrave Dictionary of Economics, 1-8, 578-583.

Buyuksahin, B., \& Harris, J.H. (2011). Do speculators drive crude oil futures prices? The Energy Journal, $32(2)$.

Büyükşahin, B., \& Robe, M.A. (2014). Speculators, commodities and cross-market linkages. Journal of International Money and Finance, 42, 38-70.

Caballero, R.J., Farhi, E., \& Gourinchas, P.O. (2008). Financial crash, commodity prices and global imbalances (Tech. Rep.). National Bureau of Economic Research.

Calvo, S. (1999). Capital flows to latin america: is there evidence of contagion effects? The World Bank.

Cheng, I-H., \& Xiong, W. (2014). Financialization of commodity markets. Annu. Rev. Financ. Econ., $6(1), 419-441$.

De Long, J.B., Shleifer, A., Summers, L.H., \& Waldmann, R.J. (1990). Noise trader risk in financial markets. Journal of Political Economy, 98(4), 703-738.

Ekeland, I., Lautier, D., \& Villeneuve, B. (2019). Hedging pressure and speculation in commodity markets. Economic Theory, 68(1), 83-123.

Fattouh, B., Kilian, L., \& Mahadeva, L. (2013). The role of speculation in oil markets: What have we learned so far? The Energy Journal, pp. 7-33.

Gilbert, C.L. (2010). Speculative influences on commodity futures prices 2006-2008.

Headey, D., \& Fan, S. (2008). Anatomy of a crisis: The causes and consequences of surging food prices. Agricultural Economics, 39, 375-391.

Hirshleifer, D. (1988). Risk, futures pricing, and the organization of production in commodity markets. Journal of Political Economy, 96(6), 1206-1220.

Hirshleifer, D. (1989). Futures trading, storage, and the division of risk: A multiperiod analysis. The Economic Journal, 99(397), 700-719.

$\mathrm{Hu}, \mathrm{C} ., \mathrm{Li}, \mathrm{Z} ., \quad \&$ Liu, X. (2020). Liquidity shocks, commodity financialization, and market comovements. Journal of Futures Markets.

IMF, International Monetary Fund. (2018). Special feature: Commodity market developments and forecasts with a focus on recent trends in energy demand. Special Feature: Commodity Market Developments and Forecasts with a Focus on Recent Trends in Energy Demand. Retrieved from https://www.imf.org/ /media/Files/Research/CommodityPrices/WEOSpecialFeature/SFOctober2 018.ashx

Irwin, S.H., \& Sanders, D.R. (2012a). Financialization and structural change in commodity futures markets. Journal of Agricultural and Applied Economics, 44(3), 371-396.

Irwin, S.H., \& Sanders, D.R. (2012b). Testing the masters hypothesis in commodity futures markets. Energy Economics, 34(1), 256-269.

Irwin, S.H., Sanders, D.R., \& Merrin, R.P. (2009). Devil or angel? The role of speculation in the recent commodity price boom (and bust). Journal of Agricultural and Applied Economics, 41(2), 377391.

Isleimeyyeh, M. (2020). The role of financial investors in determining the commodity futures risk premium. Journal of Futures Markets.

Jacks, D.S. (2019). From boom to bust: A typology of real commodity prices in the long run. Cliometrica, 13(2), 201-220.

Kim, A. (2015). Does futures speculation destabilize commodity markets? Journal of Futures Markets, 35(8), 696-714.

King, M.A., \& Wadhwani, S. (1990). Transmission of volatility between stock markets. The Review of Financial Studies, 3(1), 5-33.

Liu, P., \& Tang, K. (2010). Bubbles in the commodity asset class: Detection and sources. SSRN eLibrary (SSRN).

Masters, M.W. (2008, May 20). Testimony before the committee on homeland security and governmental affairs. US Senate, Washington. 
Miller, E.M. (1977). Risk, uncertainty, and divergence of opinion. The Journal of Finance, 32(4), 11511168.

Ordu, B.M., Oran, A., \& Soytas, U. (2018). Is food financialized? yes, but only when liquidity is abundant. Journal of Banking \& Finance, 95, 82-96.

Peters, M., Langley, S.V., \& Westcott, P.C. (2009). Agricultural commodity price spikes in the 1970s and 1990s: Valuable lessons for today (Tech. Rep.).

Robe, M.A., \& Wallen, J. (2016). Fundamentals, derivatives market information and oil price volatility. Journal of Futures Markets, 36(4), 317-344.

Roberts, M.J., \& Schlenker, W. (2009). World supply and demand of food commodity calories. American Journal of Agricultural Economics, 91(5), 1235-1242.

Robles, M., Torero, M., \& von Braun, J. (2009). When speculation matters (issue brief 57). Washington, DC: International Food Policy Research Institute. Available online: http://www. ifpri. org/pubs/ib/ib57.asp

Sanders, D.R., \& Irwin, S.H. (2010). A speculative bubble in commodity futures prices? Cross-sectional evidence. Agricultural Economics, 41(1), 25-32.

Sanders, D.R., Irwin, S.H., \& Merrin, R.P. (2010). The adequacy of speculation in agricultural futures markets: Too much of a good thing? Applied Economic Perspectives and Policy, 32(1), 77-94.

Sarris, A. (2009). Factors affecting recent and future price volatility of food commodities. Proceedings "Schriften der Gesellschaft für Wirtschafts-und Sozialwissenschaften des Land- baues eV", 44(874-2017-1065), 29-48.

Tang, K., \& Xiong, W. (2012). Index investment and the financialization of commodities. Financial Analysts Journal, 68(6), 54-74.

Trostle, R. (2008). Global Agricultural Supply and Demand: Factors Contributing to the Recent Increase in Food Commodity Prices. USDA, United States Department of Agriculture. Retrieved from https://www.ers.usda.gov/webdocs/outlooks/40463/12274_wrs0801_1_.pdf?v=8455

Trostle, R. (2011). Why have food commodity prices risen again? DIANE Publishing.

Van der Ploeg, F. (2011). Natural resources: Curse or blessing? Journal of Economic Literature, 49(2), $366-420$.

Went, P., Jirasakuldech, B., \& Emekter, R. (2009). Bubbles in commodities markets. Available at SSRN 134276. 